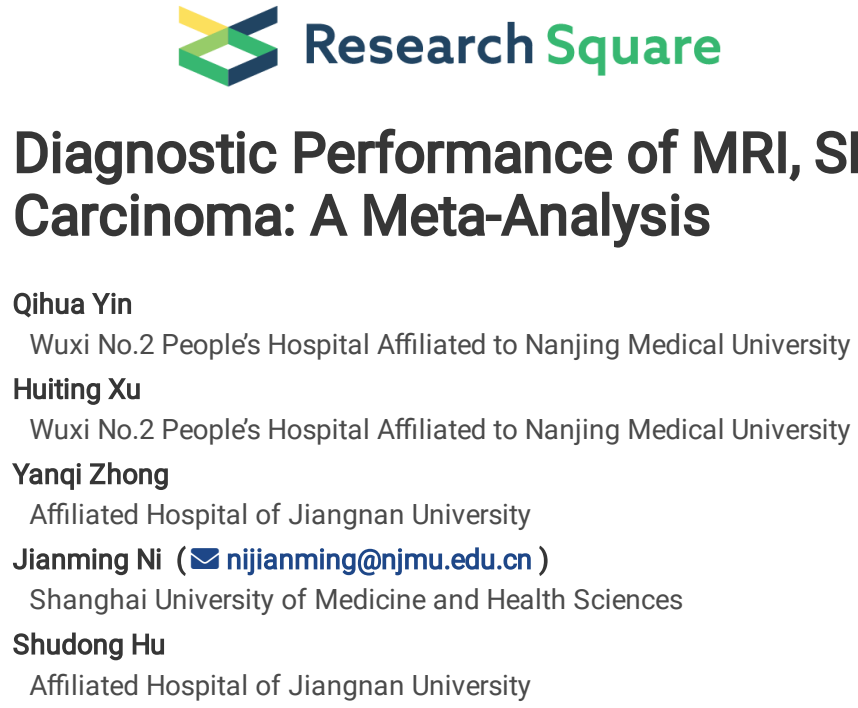

\title{
Diagnostic Performance of MRI, SPECT, and PET in Detecting Renal Cell Carcinoma: A Meta-Analysis
}




\section{Abstract}

Background: Renal cell carcinoma (RCC) is one of the most common malignancies worldwide. Noninvasive imaging techniques, such as magnetic resonance imaging (MRI), single photon emission computed tomography (SPECT), and positron emission tomography (PET), have been involved in increasing evolution to detect RCC. This meta-analysis aims to compare to compare the value of MRI, SPECT, and PET in the diagnosis of RCC, and to provide evidence for decision-making in terms of further research and clinical settings.

Methods: Electronic databases including PubMed, Web of Science, Embase, and Cochrane Library were systemically searched. Studies concerning MRI, SPECT, and PET for the detection of RCC were included. Pooled sensitivity, specificity, positive likelihood ratio (PLR), negative likelihood ratio (NLR), diagnostic odds ratio (DOR), with their respective $95 \%$ confidence interval (Cls) and the area under the summary receiver operating characteristic (SROC) curve (AUC) were calculated.

Results: A total of 44 articles were finally detected for inclusion in this meta-analysis. The pooled sensitivities of MRI, SPECT, and PET were $0.80,0.81$, and 0.88 , respectively. Their respective overall specificities were $0.90,0.54$, and 0.87 . Results in the subgroup analysis of the performance of SPECT that the pooled sensitivity, specificity, and AUC of the prospective SPECT studies included were $0.80,0.42,0.80$, respectively. In the analysis of $18 \mathrm{~F}-\mathrm{FDG}$ PET, the pooled sensitivity, specificity, and AUC were $0.88,0.86$, and 0.92 , respectively. PET studies showed a pooled sensitivity, specificity, and AUC of $0.80,0.85$, and 0.85 , respectively in the diagnosis of primary RCC. The pooled sensitivity, specificity, and AUC of PET studies in detecting recurrent or metastatic RCC were 0.93 , 0.88 , and 0.94 .

Conclusion: Our meta-analysis manifests that MRI and PET present better diagnostic value for the detection of RCC in comparison with SPECT. PET is superior in the diagnosis of recurrent or metastatic RCC.

\section{Introduction}

Renal cancer is one of the most frequently diagnosed cancers worldwide, which ranks the 6th most frequently confirmed malignant tumor in men and the 8th in women [1]. $90 \%$ of all renal malignant tumors tend to be renal cell carcinoma (RCC) [2]. There are three major histological subtypes of renal cell carcinoma: clear cell RCC, papillary RCC, and chromophobe RCC [3]. It is manifested that over one-half of patients with renal cell carcinoma are asymptomatic [4]. Unfortunately, approximately $33-50 \%$ of suspected patients are diagnosed with metastatic diseases at the time of initial detection, furthermore, $20-40 \%$ of patients with confirmed RCC progress to metastatic diseases even after surgical resection $[5,6]$. Consequently, timely and accurate detection of the early stage and advanced stage of the disease is of great significance.

Biopsy diagnosis is still the gold standard for confirmation of RCC although it is an invasive modality that may result in unnecessary adverse outcomes [7]. Various noninvasive imaging approaches are commonly employed in the detection of RCC [8]. For decades, ultrasound has been used as one of the first-line modalities for diagnostic imaging of patients with renal lesions due to its cost-effective nature, however, the efficacy of renal imaging is not satisfactory especially in patients with suspected malignancies [8]. Although computed tomography (CT) has been utilized as the confirmative standard for RCC imaging for decades, it manifested poor performance in differentiation among solid masses, fat-poor AML, and oncocytoma [9, 10]. Compared to CT, magnetic resonance imaging (MRI) plays an increasingly important role in the diagnosis and restaging of RCC, particularly in patients with unclear results, allergic reactions, pregnancies, as it has no ionizing radiation exposure, superior soft tissue resolution [11, 12]. In recent years, targeted imaging approaches have made great progression in the diagnosis of RCC. Single photon emission computed tomography-computed tomography (SPECT) imaging is used to differentiate RCC and detect metastases in renal cancer [13, 14]. Furthermore, positron emission tomography (PET) imaging utilizing ${ }^{18} \mathrm{~F}$-fluoro-deoxy-glucose (FDG) and other tracers ( ${ }^{124}$ I-girentuximab, ${ }^{68} \mathrm{Ga}$-DOTATOC, ${ }^{11} \mathrm{C}$-acetate, ${ }^{18} \mathrm{~F}$-Fluoride) has been studied as diagnostic biomarkers in RCC [15-20]. Especially, PET plays an important role in the detection of recurrent or metastatic RCC [20,21].

As far as we are concerned, a large number of studies have assessed the diagnostic performance of non-invasive approaches in terms of RCC, nevertheless, the results are heterogeneous $[13,16,20-24]$. This study aimed to generate a more comprehensive comparison of the diagnostic performance of MRI, SPECT, and PET in the detection of RCC by conducting a meta-analysis, and subsequently to guide the diagnosis and differentiation of RCC in the field of scientific research and clinical application.

\section{Materials And Methods}

The entire process of this meta-analysis was conducted based on the Preferred Reporting Items for Systematic Reviews and Meta-analysis (PRISMA) [25].

\section{Search strategy and selection criteria}

The electronic databases of PubMed, Web of Science, Embase, and Cochrane Library were comprehensively searched with a publication date from inception to January 31, 2021. Articles in the English language were considered. The following key terms were used for the database research: "magnetic resonance imaging", “MRI”, "single-photon emission computed tomography”, “SPECT”, "positron emission tomography”, “PET”, "renal cell carcinoma”. Besides, we manually screened the references of the articles included for more potentially eligible studies. The inclusion criteria of studies were as follows: 1) MRI, SPECT, and/or PET were used for the detection of RCC in patients with suspected or confirmed RCC; 2) a reference standard was utilized to assess diagnostic performance; 3 ) absolute numbers of patients with true positive (TP), false positive (FP), true negative (TN) and false negative (FN) results can be retrieved in the published articles or recalculated based on other parameters (accuracy rate, sensitivity, specificity, positive predictive value (PPV), negative predictive value (NPV), number of all participants) presented in the manuscripts. In case that the studies were undertaken by the same research group, those with the largest 
sample size or the most complete information were included to avoid duplicates. Articles were excluded if they were case reports, reviews, letters, news, conference abstracts, animal studies, or studies with insufficient data.

Two independent investigators (QY and HX) conducted the process of literature search and study inclusion. Discrepancies were resolved by discussion. If no consensus was reached, a third author (JN) was involved.

\section{Data extraction and quality assessments}

Two researchers (QY and YZ) independently performed the title and abstract screening according to the inclusion criteria. A full-text reading of the literature was conducted for the final inclusion. The following information was extracted from each study: first author's name, year of publication, study design, type of RCC (primary or recurrent/metastatic), number of patients analyzed, percentage of the male, age of the participants, reference standard, imaging modality and type of radiotracers used in the study, absolute numbers of patients with TP, TN, FP, and FN numbers.

To evaluate the methodological quality of the enrolled studies, we used the Quality Assessment of Diagnostic Accuracy Studies-2 (QUADAS-2) tool. This method contains four main components in terms of participant selection, index test, reference standard, as well as flow and timing, all the components are assessed in terms of risk of bias, and the first three components are also evaluated the concerns of applicability [26].

\section{Statistical analysis}

We calculated pooled sensitivity, specificity, positive likelihood ratio (PLR), negative likelihood ratio (NLR), diagnostic odds ratio (DOR), and the 95\% confidence intervals (Cls) and the area under the summary receiver operating characteristic (SROC) curve (AUC). A Cochran Q value and the ${ }^{2}$ statistic were used to detect the heterogeneity of studies included. $I^{2}$ statistics in the range of $0-25 \%, 25-50 \%, 50-75 \%$, and $75-100 \%$ were considered to be of insignificant, low, moderate, and high heterogeneity between studies, respectively [27]. Meta-regression was performed to investigate the possible source of heterogeneity between the included studies. A Deeks' method was introduced to statistically test the asymmetry of the funnel plot and detect publication bias. We conducted sensitivity analysis to evaluate the impacts of one single study on the overall outcomes. All statistical analyses were processed on the study basis using the Stata 15.0 software and Review Manager 5.3 software. A p value $<0.05$ was considered to be statistically significant.

\section{Results}

\section{Study selection and characteristics}

A total number of 896 articles were identified from the online databases. Among them, we excluded 135 duplicates and 640 irrespective studies based on an initial screening of titles and abstracts. After the full text confirmation for eligibility of the remaining 121 articles, 44 articles with 50 studies and 2545 patients were identified for final inclusion in this meta-analysis. No additional studies were found through reference screening of the included papers. Figure 1 shows the flow of the database search and literature selection process. Detailed characteristics of studies included were shown in Table 1 . The results of the quality evaluation of the included studies manifested that the high quality of the included studies (Figure 2).

\section{Diagnostic performance of imaging modalities}

We performed the sensitivity analysis to assess the impacts of single study on the overall outcomes. Two SPECT studies and 4 PET studies was identified as outliers. The final numbers of studies in terms of the analysis of MRI, SPECT and PET were 16,5 and 23, respectively. The pooled sensitivity of MRI, SPECT and PET were $0.80[0.70,0.88], 0.81[0.70,0.88]$ and 0.88 [0.77, 0.94], respectively. The overall specificities were $0.90[0.84,0.94], 0.54[0.04,0.97]$ and $0.87[0.81$, 0.91] for MRI, SPECT and PET. The AUC values of MRI, SPECT and PET were 0.93 [0.90, 0.95], 0.81 [0.77, 0.84] and 0.92 [0.89, 0.94] (see Figures 3-6).

\section{Subgroup analysis of the performance of SPECT}

Two SPECT studies utilized ${ }^{99 \mathrm{~m}} \mathrm{Tc}-\mathrm{MDP}$ for nuclear tracer. ${ }^{99 \mathrm{~m}} \mathrm{Tc}-\mathrm{MIBI},{ }^{111} \mathrm{In}$-Girentuximab, and ${ }^{99 \mathrm{~m}} \mathrm{Tc}-\mathrm{EC} 20$ were used in other 3 studies respectively. Four of the 5 SPECT studies were prospective studies. The pooled sensitivity, specificity, AUC, and DOR of the prospective SPECT studies included were 0.80 [0.67, $0.89], 0.42[0.01,0.99], 0.80[0.76,0.83], 3$ [0, 258], respectively (Table 2).

\section{Subgroup analysis of the performance of PET}

The numbers of PET studies utilizing ${ }^{18} \mathrm{~F}$-FDG, ${ }^{18} \mathrm{~F}$-Fluoride, ${ }^{124}$ I-girentuximab, and ${ }^{11} \mathrm{C}$-acetate were $20,1,1$, and 1 , respectively. The pooled sensitivities of PET studies and PET/CT studies were $0.84[0.66,0.93]$ and $0.84[0.7,0.92]$, respectively, and their respective pooled specificities were $0.86[0.75,0.92]$ and 0.83 $[0.76,0.88]$. The AUCs of PET studies and PET/CT were $0.88[0.85,0.91]$ and $0.86[0.83,0.89]$. In addition, the pooled sensitivity, specificity, AUC, and DOR of the ${ }^{18} \mathrm{~F}-\mathrm{FDG}$ were $0.88[0.76,0.95], 0.86[0.80,0.91], 0.92[0.89,0.91]$, and $48[14,161]$, respectively. With respect to prospective PET studies, the pooled sensitivity, specificity and AUC were $0.86[0.65,0.89], 0.86[0.78,0.91]$ and $0.90[0.87,0.92]$. In the detection of primary RCC, PET studies revealed a pooled sensitivity, specificity, and AUC of $0.80[0.68,0.89] 0.85[0.78,0.89] 0.85[0.82,0.88]$, respectively. The pooled sensitivity, specificity, and AUC of PET studies in detecting recurrent or metastatic RCC were $0.93[0.76,0.98], 0.88$ [0.79, 0.94], and $0.94[0.92,0.96]$. More details were shown in Table 2.

\section{Heterogeneity and publication bias}

Deek's tests for publication bias yielded p values of $0.94,0.69$, and 0.02 for MRI, SPECT, and PET, which revealed that there was a possible publication bias in the pooled analysis of PET studies. 


\section{Discussion}

Renal cell carcinoma is the most commonly diagnosed subtype of kidney cancers and accounts for approximately $2-3 \%$ of all malignancies [19]. The research of Motzer et al. demonstrated that the average 5-year survival rates for patients with RCC decreased with the disease stages (I to IV), from 96-23\% [28]. Moreover, the early signs and symptoms of RRC are not specific which introduces difficulties for the early detection of this disease in primary or metastatic sites [29]. Renal biopsy is an accurate method to establish a histological diagnosis for RRC, however, it is may induce a risk of procedural adverse events [30]. Noninvasive approaches namely MRI, SPECT, and PET have been in evolution during the past decades [13,31, 32]. Based on various studies of the diagnostic value of noninvasive modalities in the detection of RCC, we carry out a meta-analysis to compare the diagnostic efficacy of these approaches.

The meta-analysis was processed on the basis of study design, type of imaging modalities, type of radiotracers, type of RCC. To our knowledge, some of these dimensions have not been discussed in relevant meta-analyses [33-35]. This is one of the strengths of this study. Results revealed that the pooled sensitivity of PET $(0.88[0.77,0.94])$ was the highest. MRI demonstrated the highest overall specificity $(0.90[0.84,0.94])$. MRI and PET showed high diagnostic performance in detecting RCC. Results of subgroup analysis manifested that PET imaging had better performance than PET combined with CT. This result was opposite to Ma's study. The possible reasons may be that Ma's study only included studies using ${ }^{18} \mathrm{~F}$-FDG while studies utilizing ${ }^{18} \mathrm{~F}$-FDG, ${ }^{18} \mathrm{~F}$-Fluoride, ${ }^{124}$ I-girentuximab, and ${ }^{11} \mathrm{C}$-acetate were enrolled [34]. Interestingly, results of the analysis of ${ }^{18} \mathrm{~F}$-FDG PET demonstrated similar diagnostic parameters to the meta-analysis of $\mathrm{Ma}$ et al. [34]. Furthermore, our research indicated that PET imaging revealed better performance in detecting recurrent or metastatic RCC than primary RCC. The underlying reason may be renal excretion of the tracers and low uptake by the primary RCC [20,36,37]. The current study confirmed this finding with a superior level of evidence.

In this meta-analysis, we conducted a detailed literature search to improve the probability of searching as many related studies as possible. Two independent investigators completed the whole process of data extraction using standardized electronic forms. Furthermore, we evaluated the heterogeneity between the studies included. There were significant heterogeneities among studies. Distinctions in the year of publication, study methodology, patient characteristics, reference standard, and radiotracers may be the source of heterogeneity. Unfortunately, meta regression was not able to be performed to investigate the likely cause of heterogeneity due to limited number of covariates extracted from the enrolled studies. Subgroup analysis was undertaken to explore the possible source of heterogeneity. For the analysis of PET, the source of heterogeneity may be attributed to the type of radiotracers, type of RCC, and study design. However, not all potential source of heterogeneity was analyzed because of the insufficient number of studies in different subgroups. On account of this limitation, the efficacy of heterogeneity assessment in the study may be biased. Besides, publication bias was detected through the Deeks' funnel plot asymmetry test in the analysis of PET studies. The publication bias may be attributed to the strict exclusion criteria of this meta-analysis. Although there is heterogeneity among studies included and publication bias, the findings of this analysis may introduce evidence and assistances concerning scientific research and clinical practice in the detection of RRC. In regard to further research, novel radiotracers with higher uptake ratios between tumor tissues to normal tissues and lower levels of renal excretion need to be further investigated on account of the results of this meta-analysis. In terms of application in the clinical setting, MRI is recommended as the favorable imaging method to help detect RCC due to lack of radiation exposure and high soft-tissue resolution. PET is more suitable for the diagnosis of recurrent or metastatic RCC than primary tumors under the current development of functional imaging modalities. Of note, combined employment of various detection techniques is may be of assistance to increase the overall diagnostic accuracy.

\section{Abbreviations}

RCC, renal cell carcinoma

MRI, magnetic resonance imaging

SPECT, single photon emission computed tomography

PET, positron emission tomography

$\mathrm{CT}$, computerized tomography

PRISMA, Preferred Reporting Items for Systematic Reviews and Meta-analysis

TP, true positive

FP, false positive

$\mathrm{TN}$, true negative

FN, false negative

PLR, positive likelihood ratio

NLR, negative likelihood ratio

DOR, diagnostic odds ratio

$\mathrm{Cl}$, confidence interval

SROC, summary receiver operating characteristic 
AUC, area under the SROC curve

QUADAS-2, Quality Assessment of Diagnostic Accuracy Studies-2

\section{Declarations}

Ethics approval and consent to participate

Not applicable.

\section{Consent for publication}

Not applicable.

\section{Availability of data and materials}

The datasets used and/or analysed during the current study available from the corresponding author on reasonable request.

\section{Competing interests}

The authors declare that they have no competing interests.

\section{Funding}

This project is funded by Construction project of Shanghai Key Laboratory of Molecular Imaging (18DZ2260400), Shanghai Municipal Education Commission (Class II Plateau Disciplinary Construction Program of Medical Technology of SUMHS, 2018-2020), Wuxi Municipal Health Commission (Z201910) and the Taihu Lake Talent Plan (2020).

\section{Authors' Contributions}

QY conceived and designed this study. $\mathrm{HX}$ and $\mathrm{YZ}$ were responsible for the collection, extraction, and analysis of the data. QY was responsible for data analysis and writing the paper. JN and SH performed the quality evaluation of the writing and polished the English language. All authors reviewed the paper and reached an agreement to approve the final manuscript.

\section{Acknowledgements}

Not applicable.

\section{References}

1. Siegel RL, Miller KD, Jemal A: Cancer statistics, 2020. CA: a cancer journal for clinicians 2020, 70(1):7-30.

2. Gray RE, Harris GT: Renal Cell Carcinoma: Diagnosis and Management. American family physician 2019, 99(3):179-184.

3. Low G, Huang G, Fu W, Moloo Z, Girgis S: Review of renal cell carcinoma and its common subtypes in radiology. World journal of radiology 2016, 8(5):484-500.

4. Jonasch E, Gao J, Rathmell WK: Renal cell carcinoma. BMJ (Clinical research ed) 2014, 349:g4797.

5. Vig SVL, Zan E, Kang SK: Imaging for Metastatic Renal Cell Carcinoma. The Urologic clinics of North America 2020, 47(3):281-291.

6. Janzen NK, Kim HL, Figlin RA, Belldegrun AS: Surveillance after radical or partial nephrectomy for localized renal cell carcinoma and management of recurrent disease. Urologic Clinics of North America 2003, 30(4):843-852.

7. Albiges L, Fay AP, McKay RR, Kaymakcalan MD, Choueiri TK: Diagnosis of Renal Cell Carcinoma: A Clinician's Perspective. Surgical pathology clinics 2015, 8(4):657-662.

8. Sankineni S, Brown A, Cieciera M, Choyke PL, Turkbey B: Imaging of renal cell carcinoma. Urologic oncology 2016, 34(3):147-155.

9. Ge J, Zhu L, Zhou J, Li G, Li Y, Li S, Wu Z, Rong J, Yuan H, Liu Y et al: Association between co-inhibitory molecule gene tagging single nucleotide polymorphisms and the risk of colorectal cancer in Chinese. Journal of cancer research and clinical oncology 2015, 141(9):1533-1544.

10. Rossi SH, Prezzi D, Kelly-Morland C, Goh V: Imaging for the diagnosis and response assessment of renal tumours. World journal of urology 2018, 36(12):1927-1942.

11. Willatt JM, Hussain HK, Chong S, Kappil M, Azar SF, Liu PS, Ruma JA, Elsayes KM: MR imaging in the characterization of small renal masses. Abdominal imaging 2014, 39(4):761-769.

12. Hudson JM, Bailey C, Atri M, Stanisz G, Milot L, Williams R, Kiss A, Burns PN, Bjarnason GA: The prognostic and predictive value of vascular response parameters measured by dynamic contrastenhanced-CT, -MRI and -US in patients with metastatic renal cell carcinoma receiving sunitinib. European radiology 2018, 28(6):2281-2290.

13. Sistani G, Bjazevic J, Kassam Z, Romsa J, Pautler S: Value of (99m)Tc-sestamibi single-photon emission computed tomography-computed tomography in the evaluation and risk stratification of renal masses. Canadian Urological Association journal = Journal de l'Association des urologues du Canada 2020 . 
14. Sohaib SA, Cook G, Allen SD, Hughes M, Eisen T, Gore M: Comparison of whole-body MRI and bone scintigraphy in the detection of bone metastases in renal cancer. The British journal of radiology 2009, 82(980):632-639.

15. Divgi CR, Uzzo RG, Gatsonis C, Bartz R, Treutner S, Yu JQ, Chen D, Carrasquillo JA, Larson S, Bevan P et al: Positron emission tomography/computed tomography identification of clear cell renal cell carcinoma: results from the REDECT trial. Journal of clinical oncology : official journal of the American Society of Clinical Oncology 2013, 31(2):187-194.

16. Nakamoto Y, Ishimori T, Shimizu Y, Sano K, Togashi K: Clinical utility of (68)Ga-DOTATOC positron emission tomography/computed tomography for recurrent renal cell carcinoma. European journal of nuclear medicine and molecular imaging 2019, 46(7):1524-1530.

17. Oyama N, Ito H, Takahara N, Miwa Y, Akino H, Kudo T, Okazawa H, Fujibayashi Y, Komatsu K, Tsukahara K et al: Diagnosis of complex renal cystic masses and solid renal lesions using PET imaging: comparison of 11C-acetate and 18F-FDG PET imaging. Clinical nuclear medicine 2014, 39(3):e208-214.

18. Sharma P, Karunanithi S, Chakraborty PS, Kumar R, Seth A, Julka PK, Bal C, Kumar R: 18F-Fluoride PET/CT for detection of bone metastasis in patients with renal cell carcinoma: a pilot study. Nuclear medicine communications 2014, 35(12):1247-1253.

19. Alongi P, Picchio M, Zattoni F, Spallino M, Gianolli L, Saladini G, Evangelista L: Recurrent renal cell carcinoma: clinical and prognostic value of FDG PET/CT. European journal of nuclear medicine and molecular imaging 2016, 43(3):464-473.

20. Youssef MA, Elshafey MH, Moghazy KM, Elrashedy AA: Dual modality imaging of positron emission tomography-computed tomography (PET-CT) in evaluation of postoperative renal cancer patients. Egyptian Journal of Radiology and Nuclear Medicine 2018, 49(4):1083-1092.

21. Win AZ, Aparici CM: Clinical effectiveness of (18)f-fluorodeoxyglucose positron emission tomography/computed tomography in management of renal cell carcinoma: a single institution experience. World journal of nuclear medicine 2015, 14(1):36-40.

22. Ozturk H: Diagnostic role of 18F-fluorodeoxyglucose positron-emission tomography/computed tomography in restaging renal cell carcinoma. Minerva urologica e nefrologica = The Italian journal of urology and nephrology 2016, 68(3):263-269.

23. Sheikhbahaei S, Jones CS, Porter KK, Rowe SP, Gorin MA, Baras AS, Pierorazio PM, Ball MW, Higuchi T, Johnson PT et al: Defining the Added Value of 99mTc-MIBI SPECT/CT to Conventional Cross-Sectional Imaging in the Characterization of Enhancing Solid Renal Masses. Clinical nuclear medicine 2017, 42(4):e188-e193.

24. Sun J, Pan L, Zha T, Xing W, Chen J, Duan S: The role of MRI texture analysis based on susceptibility-weighted imaging in predicting Fuhrman grade of clear cell renal cell carcinoma. Acta radiologica (Stockholm, Sweden : 1987) 2020:284185120951964.

25. Moher D, Liberati A, Tetzlaff J, Altman DG: Preferred reporting items for systematic reviews and meta-analyses: the PRISMA statement. International journal of surgery (London, England) 2010, 8(5):336-341.

26. Reitsma JB, Moons KG, Bossuyt PM, Linnet K: Systematic reviews of studies quantifying the accuracy of diagnostic tests and markers. Clinical chemistry 2012, 58(11):1534-1545.

27. Cumpston M, Li T, Page MJ, Chandler J, Welch VA, Higgins JP, Thomas J: Updated guidance for trusted systematic reviews: a new edition of the Cochrane Handbook for Systematic Reviews of Interventions. The Cochrane database of systematic reviews 2019, 10:Ed000142.

28. Motzer RJ, Hutson TE, Tomczak P, Michaelson MD, Bukowski RM, Oudard S, Negrier S, Szczylik C, Pili R, Bjarnason GA et al: Overall survival and updated results for sunitinib compared with interferon alfa in patients with metastatic renal cell carcinoma. Journal of clinical oncology : official journal of the American Society of Clinical Oncology 2009, 27(22):3584-3590.

29. Lyu HL, Cao JX, Wang HY, Wang ZB, Hu MG, Ma L, Wang YW, Ye HY: Differentiation between pancreatic metastases from clear cell renal cell carcinoma and pancreatic neuroendocrine tumor using doubleecho chemical shift imaging. Abdominal radiology (New York) 2018, 43(10):2712-2720.

30. Li Q, Liu YJ, Dong D, Bai X, Huang QB, Guo AT, Ye HY, Tian J, Wang HY: Multiparametric MRI Radiomic Model for Preoperative Predicting WHO/ISUP Nuclear Grade of Clear Cell Renal Cell Carcinoma. Journal of magnetic resonance imaging : JMRI 2020, 52(5):1557-1566.

31. Lindenberg L, Mena E, Choyke PL, Bouchelouche K: PET imaging in renal cancer. Current opinion in oncology 2019, 31(3):216-221.

32. Vogel C, Ziegelmüller B, Ljungberg B, Bensalah K, Bex A, Canfield S, Giles RH, Hora M, Kuczyk MA, Merseburger AS et al: Imaging in Suspected Renal-Cell Carcinoma: Systematic Review. Clinical genitourinary cancer 2019, 17(2):e345-e355.

33. Wilson MP, Katlariwala P, Murad MH, Abele J, Mclnnes MDF, Low G: Diagnostic accuracy of 99mTc-sestamibi SPECT/CT for detecting renal oncocytomas and other benign renal lesions: a systematic review and meta-analysis. Abdominal radiology (New York) 2020, 45(8):2532-2541.

34. Ma H, Shen G, Liu B, Yang Y, Ren P, Kuang A: Diagnostic performance of 18F-FDG PET or PET/CT in restaging renal cell carcinoma: a systematic review and meta-analysis. Nuclear medicine communications 2017, 38(2):156-163.

35. Wang HY, Ding HJ, Chen JH, Chao CH, Lu YY, Lin WY, Kao CH: Meta-analysis of the diagnostic performance of [18F]FDG-PET and PET/CT in renal cell carcinoma. Cancer imaging : the official publication of the International Cancer Imaging Society 2012, 12(3):464-474.

36. Noda Y, Kanematsu M, Goshima S, Suzui N, Hirose Y, Matsunaga K, Nishibori H, Kondo H, Watanabe H, Kawada H et al: 18-F fluorodeoxyglucose uptake in positron emission tomography as a pathological grade predictor for renal clear cell carcinomas. European radiology 2015, 25(10):3009-3016.

37. Nakatani K, Nakamoto Y, Saga T, Higashi T, Togashi K: The potential clinical value of FDG-PET for recurrent renal cell carcinoma. European journal of radiology 2011, 79(1):29-35.

\section{Tables}

Table 1. Study characteristics 


\begin{tabular}{|c|c|c|c|c|c|c|c|c|c|c|}
\hline $\begin{array}{l}\text { Name of the } \\
\text { first author }\end{array}$ & $\begin{array}{l}\text { Year of } \\
\text { publication }\end{array}$ & Study design & Population & $\begin{array}{l}\text { Type of } \\
\text { RCC }\end{array}$ & Reference test & $\begin{array}{l}\text { No. of } \\
\text { Patients } \\
\text { analysed }\end{array}$ & $\begin{array}{l}\text { Male, } \\
\text { No. } \\
\text { (\%) }\end{array}$ & $\begin{array}{l}\text { Age } \\
\text { (SD or } \\
\text { IQR) }\end{array}$ & Modalities & $\begin{array}{l}\text { Image } \\
\text { analysis }\end{array}$ \\
\hline Adams & 2019 & Prospective & $\begin{array}{l}\text { Suspected } \\
\text { or known } \\
\text { RCC }\end{array}$ & Primary & Histopathology & 27 & 70 & $61(14)$ & MRI & Quantitative \\
\hline Aide & 2003 & Prospective & $\begin{array}{l}\text { Suspected } \\
\text { RCC }\end{array}$ & Primary & Histopathology & 35 & 60 & $60(14)$ & PET & Qualitative \\
\hline Alongi & 2016 & Prospective & $\begin{array}{l}\text { Suspected } \\
\text { or known } \\
\text { RCC }\end{array}$ & Primary & $\begin{array}{l}\text { Histopathology } \\
\text { and/or other } \\
\text { imaging }\end{array}$ & 104 & 69 & 63 (13) & $\mathrm{PET} / \mathrm{CT}$ & Qualitative \\
\hline Aslan & 2018 & Retrospective & $\begin{array}{l}\text { Known } \\
\text { RCC }\end{array}$ & Primary & Histopathology & 49 & 52 & $62(14)$ & MRI & Qualitative \\
\hline Bertagna & 2013 & Retrospective & $\begin{array}{l}\text { Known } \\
\text { RCC }\end{array}$ & Primary & Histopathology & 68 & 72 & $68(4)$ & $\mathrm{PET} / \mathrm{CT}$ & Qualitative \\
\hline Chang & 2003 & Retrospective & $\begin{array}{l}\text { Known } \\
\text { RCC }\end{array}$ & Primary & Histopathology & 15 & 47 & $56(15)$ & PET & Qualitative \\
\hline Chen & 2014 & Retrospective & $\begin{array}{l}\text { Suspected } \\
\text { RCC }\end{array}$ & Primary & Histopathology & 35 & 57 & $\begin{array}{l}57(29- \\
77)\end{array}$ & MRI & Qualitative \\
\hline Chen & 2015 & Prospective & $\begin{array}{l}\text { Suspected } \\
\text { RCC }\end{array}$ & Primary & Histopathology & 71 & 75 & $\begin{array}{l}50(21- \\
78)\end{array}$ & MRI & Qualitative \\
\hline Choi & 2021 & Retrospective & $\begin{array}{l}\text { Known } \\
\text { RCC }\end{array}$ & Primary & Histopathology & 110 & 67 & NR & MRI & Qualitative \\
\hline Dilhuydy & 2006 & Retrospective & $\begin{array}{l}\text { Suspected } \\
\text { or known } \\
\text { RCC }\end{array}$ & $\begin{array}{l}\text { Recurrent } \\
\text { or } \\
\text { metastatic }\end{array}$ & Histopathology & 18 & NR & $57(13)$ & $\mathrm{PET} / \mathrm{CT}$ & Qualitative \\
\hline Ding & 2016 & Retrospective & $\begin{array}{l}\text { Suspected } \\
\text { or known } \\
\text { RCC }\end{array}$ & Primary & Histopathology & 35 & 58 & $52(12)$ & MRI & Qualitative \\
\hline Divgi & 2013 & Prospective & $\begin{array}{l}\text { Suspected } \\
\text { or known } \\
\text { RCC }\end{array}$ & Primary & Histopathology & 204 & 63 & $56(12)$ & $\mathrm{PET} / \mathrm{CT}$ & Qualitative \\
\hline Fisher & 2008 & Prospective & $\begin{array}{l}\text { Suspected } \\
\text { or known } \\
\text { RCC }\end{array}$ & Primary & Histopathology & 122 & 64 & $\begin{array}{l}58(32- \\
80)\end{array}$ & SPECT & Qualitative \\
\hline Fuccio & 2014 & Retrospective & $\begin{array}{l}\text { Known } \\
\text { RCC }\end{array}$ & Primary & Histopathology & 69 & NR & $\begin{array}{l}62(36- \\
86)\end{array}$ & $\mathrm{PET} / \mathrm{CT}$ & Qualitative \\
\hline Goldberg & 1997 & Prospective & $\begin{array}{l}\text { Suspected } \\
\text { or known } \\
\text { RCC }\end{array}$ & Primary & Histopathology & 10 & 57 & $\begin{array}{l}49(37- \\
76)\end{array}$ & PET & Qualitative \\
\hline Jadvar & 2003 & Retrospective & $\begin{array}{l}\text { Suspected } \\
\text { or known } \\
\text { RCC }\end{array}$ & Primary & $\begin{array}{l}\text { Histopathology } \\
\text { and clinical } \\
\text { follow-up }\end{array}$ & 25 & 72 & NR & PET & Qualitative \\
\hline Johnson & 2019 & Retrospective & $\begin{array}{l}\text { Suspected } \\
\text { or known } \\
\text { RCC }\end{array}$ & Primary & Histopathology & 57 & NR & $62(15)$ & MRI & Qualitative \\
\hline Kang & 2004 & Prospective & $\begin{array}{l}\text { Suspected } \\
\text { or known } \\
\text { RCC }\end{array}$ & Primary & Histopathology & 17 & 74 & $\begin{array}{l}59 \otimes 28- \\
79)\end{array}$ & PET & Qualitative \\
\hline Kumar & 2010 & Retrospective & $\begin{array}{l}\text { Known } \\
\text { RCC }\end{array}$ & Primary & $\begin{array}{l}\text { Histopathology } \\
\text { and clinical } \\
\text { follow-up and } \\
\text { conventional } \\
\text { imaging } \\
\text { finding }\end{array}$ & 103 & 87 & $57(12)$ & $\mathrm{PET} / \mathrm{CT}$ & Qualitative \\
\hline Kwon & 2015 & Prospective & $\begin{array}{l}\text { Suspected } \\
\text { or known } \\
\text { RCC }\end{array}$ & Primary & $\begin{array}{l}\text { Histopathology } \\
\text { and clinical } \\
\text { follow-up }\end{array}$ & 73 & 60 & $\begin{array}{l}52(28- \\
71)\end{array}$ & MRI & Qualitative \\
\hline $\mathrm{Li}$ & 2020 & Retrospective & $\begin{array}{l}\text { Known } \\
\text { RCC }\end{array}$ & Primary & Histopathology & 127 & 78 & $56(12)$ & MRI & Quantitative \\
\hline Lima & 2020 & Retrospective & $\begin{array}{l}\text { Known } \\
\text { RCC }\end{array}$ & Primary & Histopathology & 47 & 55 & $61(12)$ & MRI & Qualitative \\
\hline Lyu & 2018 & Retrospective & $\begin{array}{l}\text { Suspected } \\
\text { metastatic } \\
\text { RCC }\end{array}$ & $\begin{array}{l}\text { Recurrent } \\
\text { or } \\
\text { metastatic }\end{array}$ & Histopathology & 35 & 54 & $55(15)$ & MRI & Qualitative \\
\hline
\end{tabular}




\begin{tabular}{|c|c|c|c|c|c|c|c|c|c|c|}
\hline Majhail & 2003 & Retrospective & $\begin{array}{l}\text { Suspected } \\
\text { metastatic } \\
\text { RCC }\end{array}$ & $\begin{array}{l}\text { Recurrent } \\
\text { or } \\
\text { metastatic }\end{array}$ & Histopathology & 36 & 79 & $\begin{array}{l}63(45- \\
82)\end{array}$ & PET & Qualitative \\
\hline Miyakita & 2002 & Retrospective & $\begin{array}{l}\text { Known } \\
\text { RCC }\end{array}$ & Primary & Histopathology & 19 & 79 & $57(10)$ & PET & Qualitative \\
\hline Muselaers & 2013 & Retrospective & $\begin{array}{l}\text { Suspected } \\
\text { RCC }\end{array}$ & Primary & Histopathology & 29 & 41 & $64(8)$ & SPECT & Qualitative \\
\hline Nakamoto & 2019 & Retrospective & $\begin{array}{l}\text { Suspected } \\
\text { or known } \\
\text { recurrent } \\
\text { RCC }\end{array}$ & Primary & Histopathology & 25 & 76 & $\begin{array}{l}64(38- \\
86)\end{array}$ & $\mathrm{PET} / \mathrm{CT}$ & Qualitative \\
\hline Nakatani & 2011 & Retrospective & $\begin{array}{l}\text { Suspected } \\
\text { recurrent } \\
\text { RCC }\end{array}$ & Primary & $\begin{array}{l}\text { Histopathology } \\
\text { and clinical } \\
\text { follow-up }\end{array}$ & 28 & 75 & $\begin{array}{l}63(45- \\
78)\end{array}$ & PET & Qualitative \\
\hline Oyama & 2014 & Prospective & $\begin{array}{l}\text { Suspected } \\
\text { RCC }\end{array}$ & Primary & Histopathology & 34 & NR & $\begin{array}{l}67(38- \\
87)\end{array}$ & PET & Qualitative \\
\hline Ozturk & 2016 & Retrospective & $\begin{array}{l}\text { Suspected } \\
\text { recurrent } \\
\text { or } \\
\text { metastatic } \\
\text { lesions }\end{array}$ & $\begin{array}{l}\text { Recurrent } \\
\text { or } \\
\text { metastatic }\end{array}$ & $\begin{array}{l}\text { Histopathology } \\
\text { or clinical } \\
\text { follow-up }\end{array}$ & 132 & 68 & $61(12)$ & PET & Qualitative \\
\hline Ozulker & 2011 & Prospective & $\begin{array}{l}\text { Suspected } \\
\text { RCC }\end{array}$ & Primary & Histopathology & 18 & 44 & $57(11)$ & $\mathrm{PET} / \mathrm{CT}$ & Qualitative \\
\hline Park & 2009 & Retrospective & $\begin{array}{l}\text { Suspected } \\
\text { recurrent } \\
\text { or } \\
\text { metastatic } \\
\text { lesions }\end{array}$ & $\begin{array}{l}\text { Recurrent } \\
\text { or } \\
\text { metastatic }\end{array}$ & $\begin{array}{l}\text { Histopathology } \\
\text { or by clinical } \\
\text { follow-up }\end{array}$ & 63 & 75 & $\begin{array}{l}54(31- \\
76)\end{array}$ & $\mathrm{PET} / \mathrm{CT}$ & Qualitative \\
\hline Purkayastha & 2020 & Retrospective & $\begin{array}{l}\text { Known } \\
\text { RCC }\end{array}$ & Primary & Histopathology & 43 & 82 & $\begin{array}{l}64 \\
(38- \\
85)\end{array}$ & MRI & Quantitative \\
\hline Ramdave & 2001 & Prospective & $\begin{array}{l}\text { Suspected } \\
\text { or known } \\
\text { primary } \\
\text { RCC }\end{array}$ & Primary & Histopathology & 17 & 56 & $\begin{array}{l}61(32- \\
79)\end{array}$ & PET & Qualitative \\
\hline Safaei & 2002 & Prospective & $\begin{array}{l}\text { Suspected } \\
\text { RCC }\end{array}$ & Primary & Histopathology & 36 & 78 & $54(11)$ & PET & Qualitative \\
\hline Sharma & 2014 & Prospective & $\begin{array}{l}\text { Suspected } \\
\text { metastatic } \\
\text { RCC }\end{array}$ & $\begin{array}{l}\text { Recurrent } \\
\text { or } \\
\text { metastatic }\end{array}$ & Histopathology & 16 & 75 & $53(14)$ & $\mathrm{PET} / \mathrm{CT}$ & Qualitative \\
\hline Sheikhbahaei & 2017 & Prospective & $\begin{array}{l}\text { Suspected } \\
\text { RCC }\end{array}$ & Primary & Histopathology & 48 & 73 & $\begin{array}{l}59(40- \\
81)\end{array}$ & SPECT/CT & Qualitative \\
\hline Sistani & 2020 & Prospective & $\begin{array}{l}\text { Known } \\
\text { RCC }\end{array}$ & Primary & Histopathology & 31 & 79 & $\begin{array}{l}60(30- \\
83)\end{array}$ & SPECT/CT & Qualitative \\
\hline Sohaib & 2009 & Prospective & $\begin{array}{l}\text { Suspected } \\
\text { metastatic } \\
\text { RCC }\end{array}$ & $\begin{array}{l}\text { Recurrent } \\
\text { or } \\
\text { metastatic }\end{array}$ & Histopathology & 47 & 70 & $\begin{array}{l}62 \\
(29- \\
79)\end{array}$ & SPECT/MRI & Qualitative \\
\hline Sun & 2020 & Retrospective & $\begin{array}{l}\text { Known } \\
\text { RCC }\end{array}$ & Primary & Histopathology & 45 & 60 & $57(12)$ & MRI & Quantitative \\
\hline Win & 2015 & Retrospective & $\begin{array}{l}\text { Suspected } \\
\text { metastatic } \\
\text { RCC }\end{array}$ & $\begin{array}{l}\text { Recurrent } \\
\text { or } \\
\text { metastatic }\end{array}$ & Histopathology & 315 & 85 & 47.5 & PET/CT & Qualitative \\
\hline $\mathrm{Wu}$ & 2002 & Prospective & $\begin{array}{l}\text { Suspected } \\
\text { metastatic } \\
\text { RCC }\end{array}$ & $\begin{array}{l}\text { Recurrent } \\
\text { or } \\
\text { metastatic }\end{array}$ & Histopathology & 52 & 67 & $(46-73)$ & SPECT/PET & Qualitative \\
\hline Youssef & 2018 & Prospective & $\begin{array}{l}\text { Suspected } \\
\text { metastatic } \\
\text { RCC }\end{array}$ & $\begin{array}{l}\text { Recurrent } \\
\text { or } \\
\text { metastatic }\end{array}$ & Histopathology & 20 & 65 & NR & $\mathrm{PET} / \mathrm{CT}$ & Qualitative \\
\hline Zhao & 2020 & Retrospective & $\begin{array}{l}\text { Known } \\
\text { RCC }\end{array}$ & Primary & Histopathology & 35 & 69 & 61 & MRI & Quantitative \\
\hline
\end{tabular}

RCC, renal cell carcinoma. SD, standard deviation. IQR, interquartile range. MRI, magnetic resonance imaging. SPECT, single photon emission computed tomography. PET, positron emission tomography. NR, not reported.

Table 2. Results of Subgroup analysis 


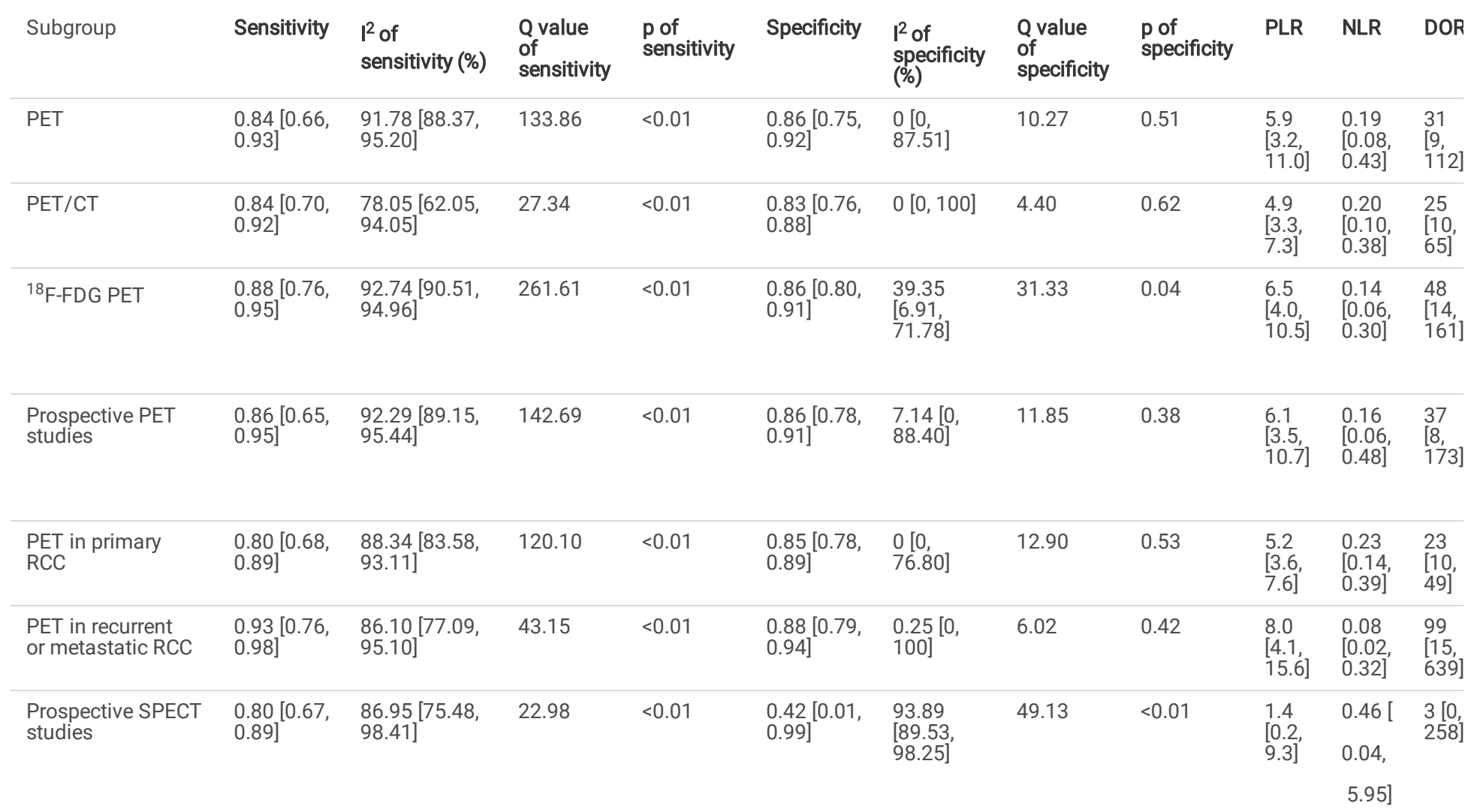

PET, positron emission tomography. SPECT, single photon emission computed tomography. PLR, positive likelihood ratio. NLR, negative likelihood ratio. DOR, diagnostic odds ratio. SROC, summary receiver operating characteristic. AUC, area under the SROC curve.

\section{Figures}




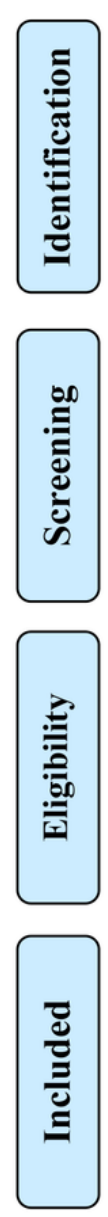
Records identified through database searching
$(\mathrm{n}=896)$

Additional records identified through other sources $(\mathrm{n}=0)$

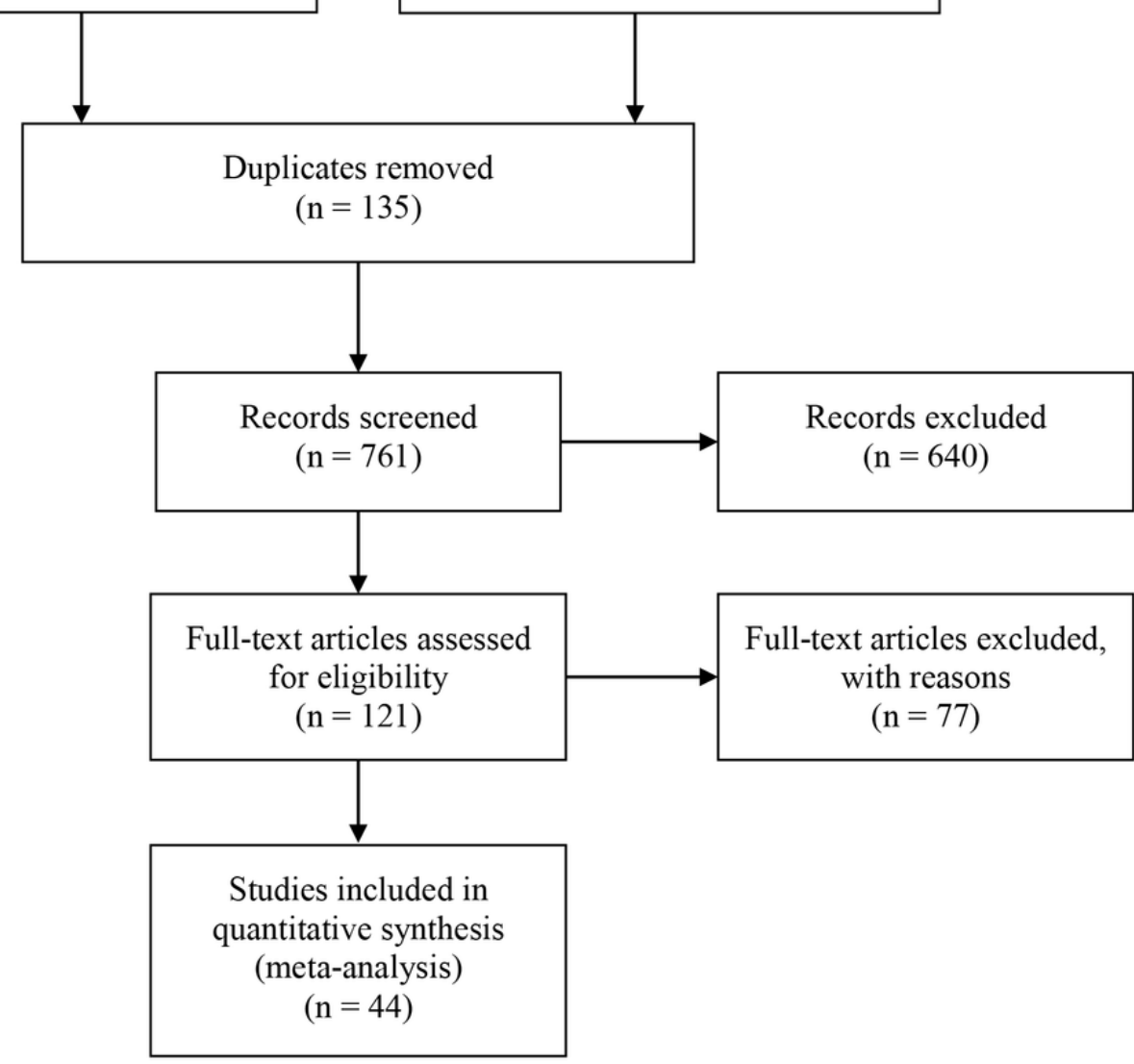

Figure 1

Search results and flow chart of the meta-analysis.

\begin{tabular}{|l|llllll|} 
Patient Selection \\
Index Test
\end{tabular}

Figure 2

Methodological assessment of studies included on the QUADAS-2 tool. 


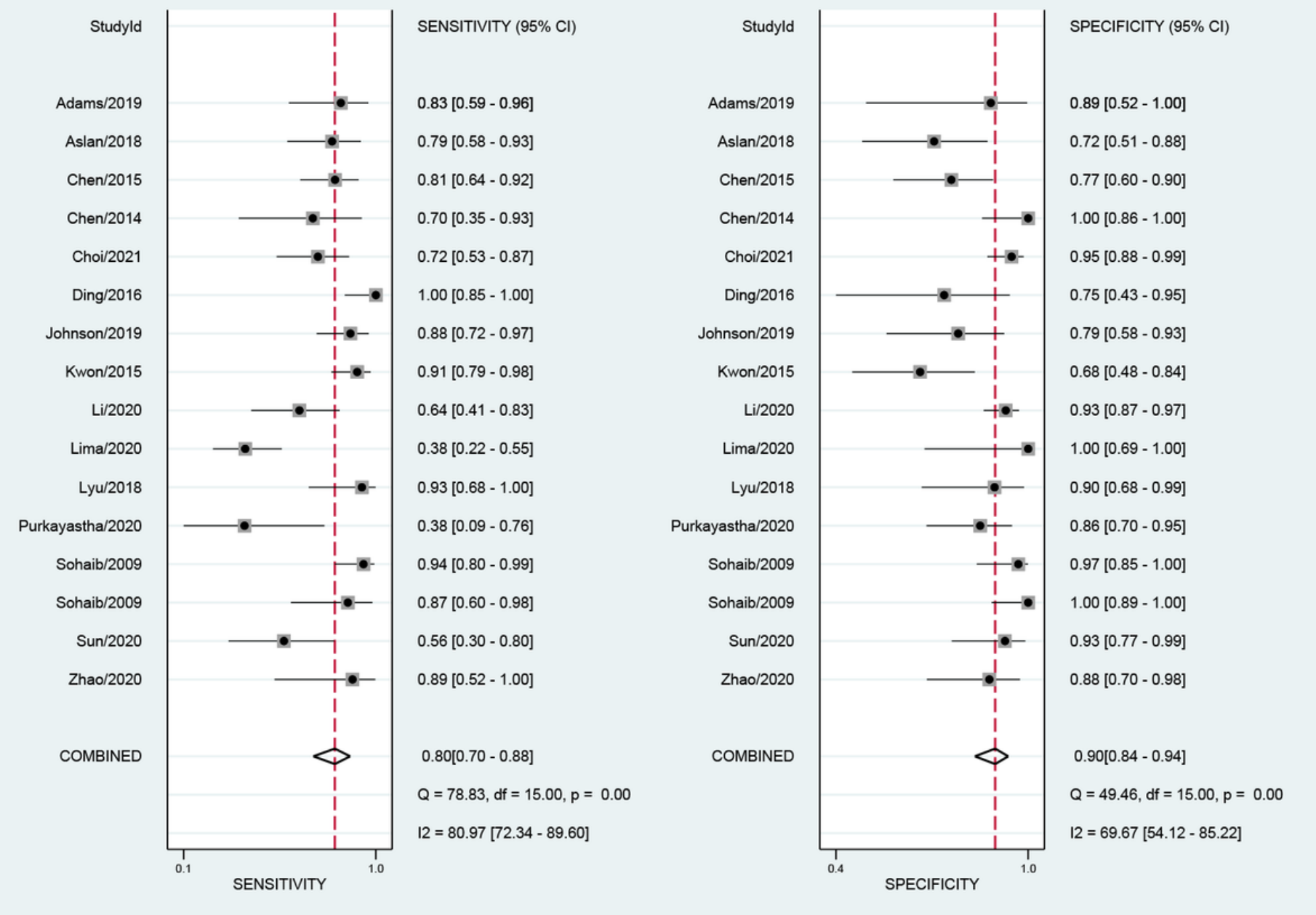

\section{Figure 3}

Forest plot for the detection performance of MRI 


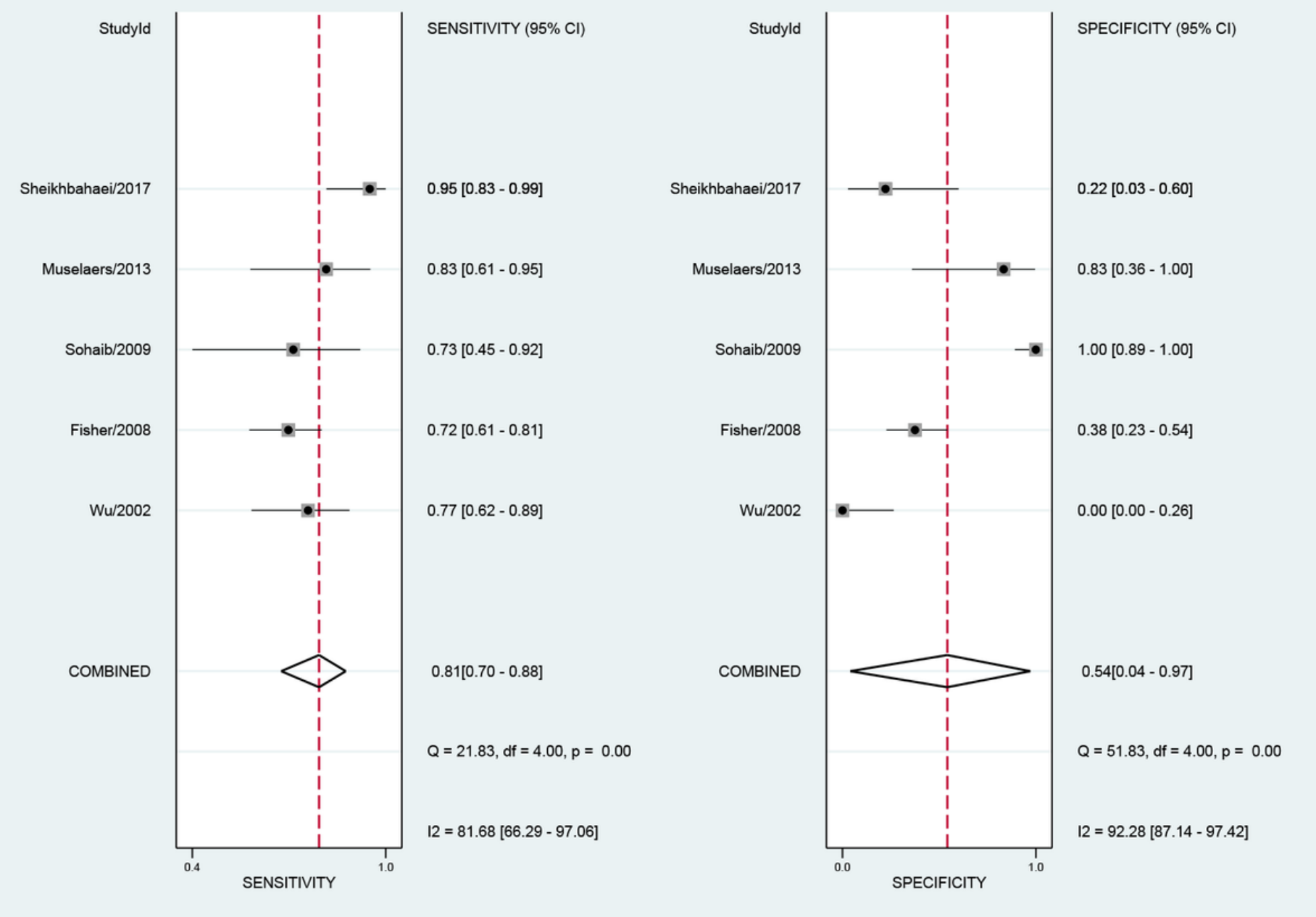

Figure 4

Forest plot for the detection performance of SPECT 


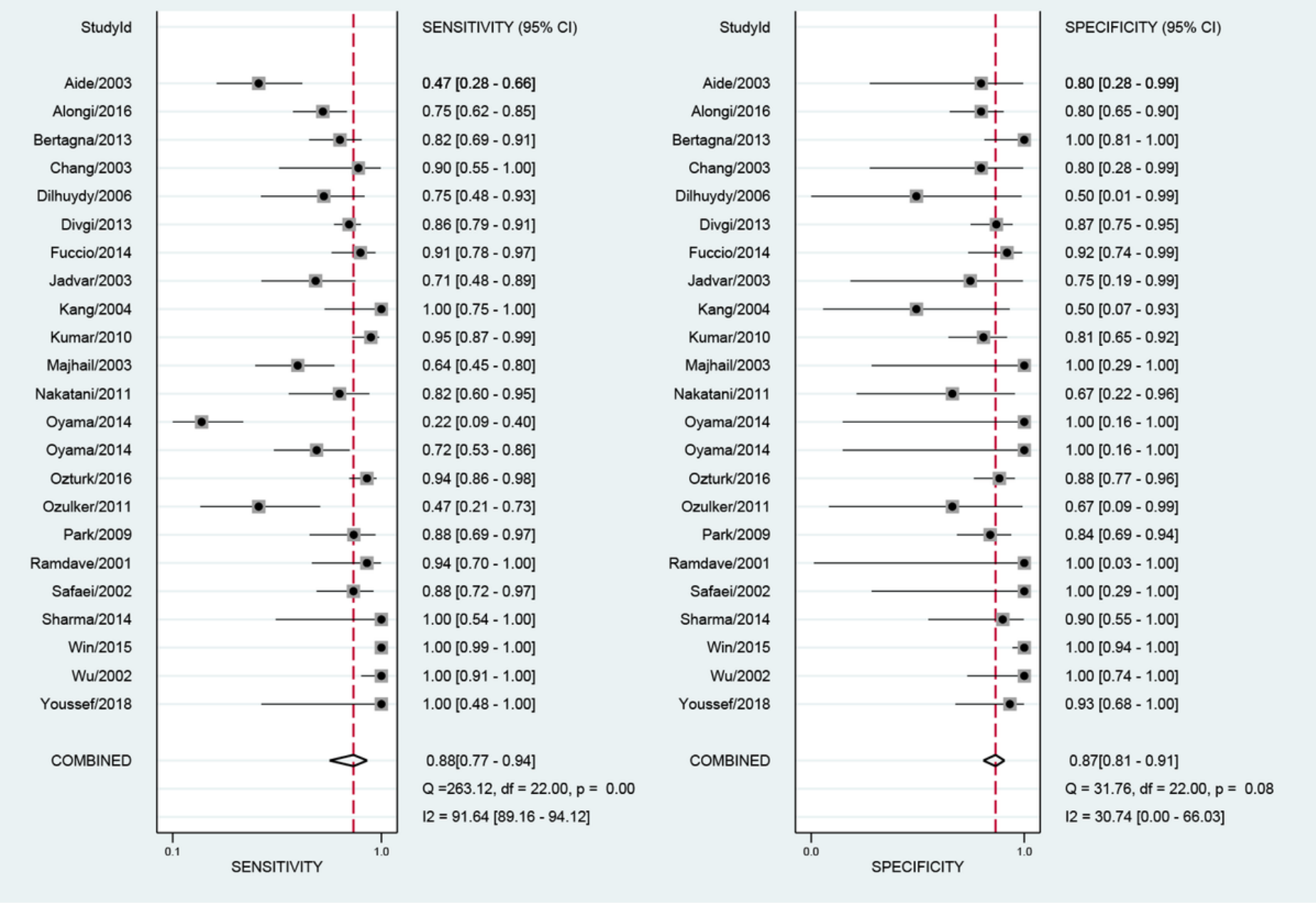

\section{Figure 5}

Forest plot for the detection performance of PET 
A

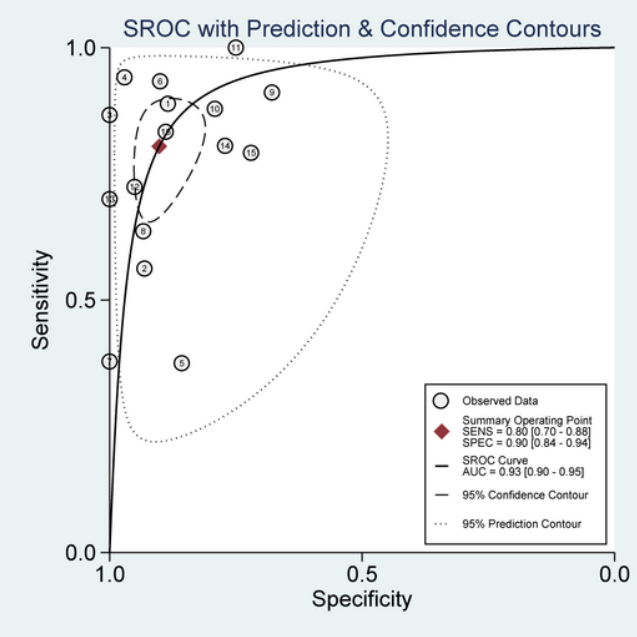

$\mathrm{B}$

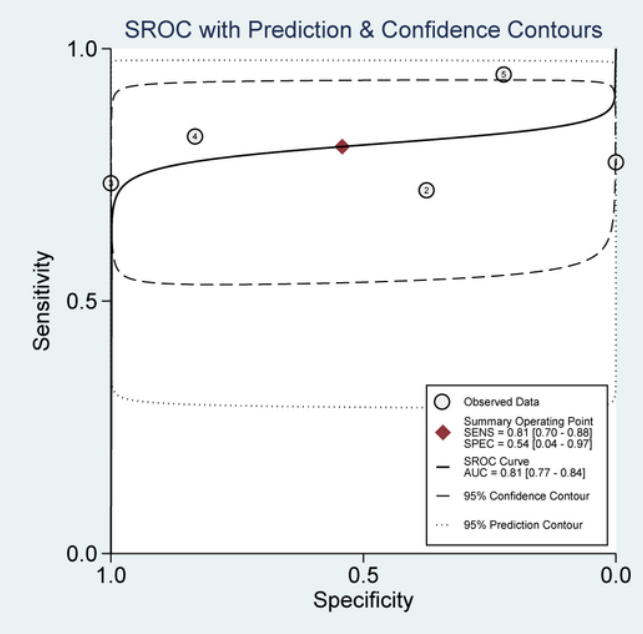

$\mathrm{C}$

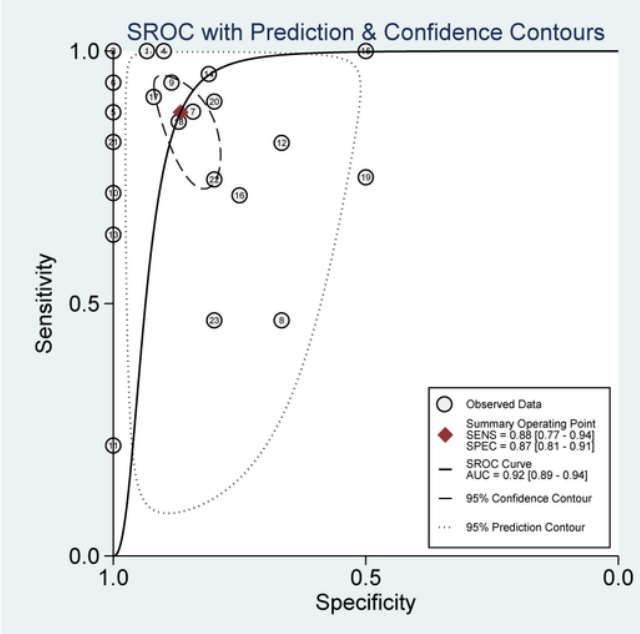

\section{Figure 6}

SROC curves for diagnostic performance of MRI, SPECT and PET. A: SROC curve for diagnostic performance of MRI. B: SROC curve for diagnostic performance of SPECT. C: SROC curve for diagnostic performance of PET. 